\title{
Ideological Manipulation \\ in the Translations of English \\ and American Literature \\ into the Russian Language
}

\author{
Natalya V. Klimovich* \\ Siberian Federal University \\ 79 Svobodny, Krasnoyarsk, 660041, Russia
}

Received 03.07.2016, received in revised form 01.12.2016, accepted 06.02.2017

\begin{abstract}
Translations of English and American literature of the late 19th-early 20th century, carried out in the Soviet period, are characterized by the strong ideological influence. Being strongly affected by the ideology of that epoch, translators made numerous alterations into the translated Russian texts of the literary works under study. Comparing original and translated texts, the author tries to identify the most common strategies of ideological manipulation in translation, used by the Soviet translators to comply with the requirements set by institutional censorship and the ruling party in the country at that period.
\end{abstract}

Keywords: manipulation, ideology, translation, transformation, manipulation strategies, conscious manipulation, unconscious manipulation.

DOI: 10.17516/1997-1370-0043.

Research area: philology; culture studies.

\section{Introduction}

Being one of the understudied phenomena in the translation studies, manipulation in translation in general, and ideological manipulation in particular, attracts researchers' attention all over the world (A. Lefevere, S. Bassnett, A. Kramina, Li Li, Mei Zhang, Katayoon Afzali, Thomas Jacques, Nasser Rashidi, Elham Karimi Fam, Shokoufeh Amiri; Abdollah Baradaran, et al). Manipulation as translator's handling of a text which results in the adaptation of the text for the target audience taking into account cultural, ideological, linguistic and literary differences between the cultures in contact, which takes place within a particular cultural setting (A. Kramina) has been a subject of numerous contemporary studies. Although the issue to what extend should a translator alter the source text is still topical.

\section{Theoretical framework}

Manipulation as "making someone think or behave exactly as you want them to by skillfully deceiving or influencing them" (Longman Dictionary of Contemporary English, 2005, p. 1001) has been attracting researches' attention for decades. The researches study

(C) Siberian Federal University. All rights reserved

* Corresponding author E-mail address: klimovich7979@mail.ru 
crowd manipulation (C. Stott), data manipulation (J. Gardenier, D. Resnik), market manipulation (S. D. Ledgerwood, p. R. Carpenter), media manipulation (M. Parenti) and psychological manipulation (G. K. Simon, H. B. Braiker). Manipulation, as one of the discursive social practices of dominant groups, is aimed towards the reproduction of their power. Such dominant groups may do so in many (other) ways as well, e.g. through persuasion, providing information, education, instruction and other social practices that are aimed at influencing the knowledge, beliefs and (indirectly) the actions of the recipients. This phenomenon is observed in other different forms: internet, news reports, textbooks, etc.

Manipulators make others believe or do things that are in the interest of the manipulator, the victims of manipulation. In order to be able to exercise such social control of others, however, social actors need to satisfy personal and social criteria that enable them to influence others in the first place.

The studies of manipulation in translation started from the studies by the representatives of the Manipulation School. Thus, A. Lefevere (1992) believes that translation, as rewriting of source texts which are manipulated by ideology, poetics, patronage and universe of discourse in which ideology and poetics are the most important constituents, and believes that "translation is, of course, a rewriting of an original text" (A. Lefevere,1992, p. xii).

The researcher notes that "all rewritings, whatever their intention, reflect a certain ideology and a poetics and as such manipulate literature to function in a given society in a given way. Rewriting is manipulation, undertaken in the service of power, and in its positive aspect can help in the evolution of a literature and a society" (ibid.). In this connection, the hypothesis of "linguistic determinism", developed by E. Sapir and B.L. Worf and "translator visibility" by L. Venuti determine how language users view and interpret the world around them and the level of translator mediation.

Manipulation school considers manipulation in connection with such three aspects as translation, literature and ideology. In cases of both conscious and unconscious manipulation ideology is considered as the key factor of manipulation in translation. Thus, if "translations are not in conflict with culture's ideology (standards for acceptable behavior in the target culture), they are easier to be published" (Shuttleworth, 2004, p. 87). According to C. Nord (2003) almost all the decisions taken in the process of translation are consciously or unconsciously affected by ideological criteria. Ideology plays an important role in choosing translation strategies. And in case the source text collides with the ideology of the target culture, translators may have to modify or leave out the offending parts. Ideology is the most important factor, it refers to the translator's ideology which they accept or the ideology imposed upon the translators by patronages. Different ideologies may initiate different translations, as most translators would state their culture's ideology to make their translations published easily (Mei Zhang, 754). A. Lefevere regards translation as a tool to promote the receiving culture and to reflect translators' ideological disposition, and highlights the relation between translation and culture, showing how cultural differences, presented as relativity, and cultural similarities, presented as universality, form the platform that embraces the concept of manipulation. Since the majority of the scholars agree upon the tendency of translations deviations from their original texts, the effective role of ideology in defining the translator's intended purpose is absolutely evident.

A variety of strategies are used by translators to manipulate a text, and as a consequence, target audience, ideologically. As a result of the text 
variations, made by translators, "the borders of translation ethics and visibility and invisibility of the translator in the target text is not crystal clear for most of the translation students or even translators themselves" (K. Afzali). In relation to the fact that the concept of ethics has broadened to cover the issue of faithfulness to the text and faithfulness to the audience, A. Pym (2001) writes that the scope of ethics in translation has widened and has included the translator's agency and has moved away from the descriptive paradigm towards processes of crosscultural communication. G. Toury declares that the translator's ideology is integrated in every word they choose, and during the whole process of translation (Toury, 2000).

Recently, the effect of translator' ideology on the target audience and the translator's ideological presence in translations have been noticed by the experts in the field of Critical Discourse Analysis (CDA). The Critical Discourse Analysis (CDA) focuses on the relations between language, power and ideology. Actually, CDA can be defined as an interdisciplinary approach to the study of discourse, which considers language as a form of social practice with the view that language is socially constitutive and socially shaped (originates from the school of socioconstructivism).

Teun Adrianus Van Dijk writes that cognitively speaking, manipulation is nothing special: it makes use of very general properties of discourse processing (Van Dijk, 2006, pp. 365366). It is considered that this mental model is the basis of our future memories, as well as the basis of further learning, such as the acquisition of experience-based knowledge, attitudes and ideologies. It should be noted that these mental models are unique, ad hoc and personal: it is person's individual interpretation of this particular discourse in this specific situation. Such personal models also involve the "instantiation" of general, socially shared knowledge or beliefs - so that we can actually understand other people and communication and interaction is possible in the first place - but the mental model as a whole is unique and personal. Mental models, according to Van Dijk, not only define our understanding of talk and text itself (by representing what a discourse is about), but also understanding of the whole communicative event. Such understandings are represented in "context models", which at the same time, for the speakers, operate as their dynamically changing - plans for speaking.

Thus, language is constructed within the social context and language users think differently about the entities in the world, based on their ideologies. Therefore, relationships between language, thought and ideology are powerful. N. Fairclough notes that "language connects with the social through being the primary domain of ideology and through being both a site of, and a stake in, struggles for power" (Fairclough, 1989, p. 15). Taking into account the fact that the ideological bases are different not only across various languages and cultures, but also across different users of the same language and culture, CDA tries to uncover the hidden aspects of discourse, which play an important role in shaping people's ideologies and changing social realities.

Translation is not only linguistic act, as it considers social and ideological backgrounds of the writer in order to be able to convey a message from the source text to its target equivalent. CDA investigates ideology in translation through analyzing deficiencies and redundancies of the translated texts to be able to see whether they are the results of the translator's ideological point of view or not.

\section{Point of view}

In connection with the aforementioned conscious and unconscious translators' 
manipulation in translation, the critical examination of the ideological manipulations in the contents of the source texts as well as the ideological orientations manifested in translation can show the intentional or unintentional strategies chosen by translators to manipulate a message and this will obviously influence the interpretation of the source text.

Manipulation strategies in translation "should receive much attention since the investigations of how the translator's ideological stance results in mediation and manipulation of the source text can help the best interpretation of a text as well as its translations" (N. Rashidi and E. Karimi Fam). Since the majority of the scholars agree upon the tendency of translations to deviate from their original texts, it is of great importance to recognize and deal with the possible underlying reasons. The effective role of ideology in defining the translator's intended purpose is absolutely evident.

One of the ways to eliminate "undesirable" content, determined by the existing ideology, from the translated literary works, is censorship. Censorship is the suppression of information which may be considered harmful, politically incorrect or inconvenient as determined by governments, authorities or other groups or institutions. Books censorship can be enacted at the national or sub-national level, and can carry legal penalties for their infraction. Books may also be challenged at a local, community level. As a result, books can be removed from schools or libraries, although these bans do not extend outside of that area.

\section{Manipulation in translation of English and American literature into Russian}

Based on the fact that few researches have focused on the effects of ideology in translation, especially in such literary genre such as novels, the study focuses on manipulation strategies caused by ideology in the translations of English and American literature into the Russian language.

Translation tradition of the Soviet Russia can be characterized by the repressive forces of censorship. Being translated in accordance with the Soviet ideology, translations of the analyzed literary works bear numerous evidences of manipulation, that took place due to udeological reasons.

The most widely used manipulation strategies in the translations of English and American literature of the late 19th - early 20th centuries into the Russian language are connected with biblicisms. The Soviet state aimed to break the power of all religious institutions and eventually replace religious belief with atheism. Taking into account this ideological consideration, the translated literature was supposed be in compliance with the adopted literary norms.

One of the most widely spread strategy used for ideological manipulation in translation is omissions. It is worth mentioning that these omissions are intended, determined by instititional censorship.

According to the conducted comparative and quantitative analysis of original and translated texts of English and American literature into the Russian language deletions and omissions were recognized as the most common manipulative strategies used by the translators. As the original versions were subjected to ideological censorship, some parts of them were deleted.

Omissions in translation mean leaving out a word or a phrase from the original text in the course of translating. This phenomenon can be a result of the cultural clashes between the source language and the target language. Omissions are not always considered as a drastic translation strategy, as a translator might think that an omitted word or phrase is not vital in the translated text. Sometimes the words are omitted as they are believed to be not 
essential for the text understanding. In addition, it is not always possible to translate literary word for word in fiction from one language to another, due to differences between them and omissions are inevitable.

However, in case of ideological manipulation in translation, omissions are made not due to linguistic reasons, but intentional translator's choice. Thus, numerous omissions and deletions are characteristic of "Lady Chatterley's Lover", a novel by D. H. Lawrence translated into Russian in by T. Leshchenko-Sukhomlin and I. Bagrov and M. Litvinova. As the original text if full of sexual scenes, obscene words and religious links, the novel was not easy to translate under conditions of censorship and ideological influence. The translations into the Russian altered peculiar Lawrence language. Thus, critics write of emasculation of the Russian version, as in comparison with the original version it became more ceremonious due to deletion of the so-called "four letter words" and obscene lexis.

Other examples of deletion or omission include biblicisms - words, quotations and idioms from the Bible. Thus, "The Grapes of Wrath" by John Steinbeck and "An American Tragedy" by Theodore Dreiser were also subjected to ideological censorship. "The Grapes of Wrath" is an American realist novel that describes difficult life of a poor family of American tenant farmers driven from their home in search of work and better life. Although the plot was in line with the Soviet ideology, the novel contains numerous quotations from the Bible, as the family was very religious. A large number of biblicisms were omitted in the translation of the novel by N. Volzhina (Klimovich, 2015). The fact led to changing the meaning of some parts of the text as well as emotionality and expressiveness of the original version that was lost for the Russian reader. The similar happened to "An American Tragedy", where it was impossible to delete all the Bible quotations and idioms, but the number of omissions is so high, that whole passages were deleted in the translated texts.

Omissions of biblisms made due to ideological and political reasons are also typical for the translations of D.H. Lawrence's "Sons and Lovers", T. Hardy's “Tess of the D'Ubervilles" and "The Forsyte Saga" by J. Galsworthy.

Some words and phrases were not deleted or omitted, but substituted by their synonyms or analogues. Substitution allows using a word for another one to give identical meaning and it is the most frequent and diverse kind of transformation. In case of ideological manipulation, this strategy gave the translator an opportunity to get rid of the "undesired" words and expressions that did not comply with censorship requirements. In the works of fiction under consideration substitutions changed expressive meaning of the original text, but allowed to preserve equivalence at the semantic level.

Substitutions (with synonyms-analogues) are also standard for the Soviet translation tradition (Klimovich, 2015). Thus, numerous substitutions are characteristic of "The Portrait of a Lady" by Henry James (translated by M.A. Shereshevskaia and L.E. Poliakova), and the aforementioned J. Lawrence's translation of "Lady Chatterley's Lover" and J. Stainbeck's “The Grapes of Wrath", where biblisisms were obviously identified by the translators, but consciously substituted by their semantic, but not expressive equivalents in the Russian translated versions.

This strategy gave opportunity to alter the original texts and change the "undesired" for the Soviet ideology elements with their semantic equivalents. However, getting rid of the forbidden elements, the translators managed to keep equivalence with the original texts at the semantic level.

One of the examples of substitutions are interjections with biblical links that were 
substituted with their analogues. Thus, in J. Steinbeck’s “The Grapes of Wrath” interjections My God and By God were substituted with $\underline{\text { Hy }}$ and $\underline{\partial a}$, etc. The substitution strategy used for the interjections translation changes the source text both at the semantic and expressive levels.

Antonymous translation is another strategy used in case of ideological manipulation in translation. It is a complex lexico-grammatical substitution manifested through giving opposite meaning to a word or an expression in the translated text. Negative meaning could be given to a positive construction and vice-versa, which is coupled with a replacement of a word by its antonym when translated. Under condition of ideological manipulation, negative connotation was given to the translated words and phrases that were supposed to be changed. Such phenomenon took place with the proper names originated from the Bible and interjections with proper names from the Bible.

Thus, in "The Grapes of Wrath" by J. Steinbeck such proper names as Jesus H. Christ and God Almighty were translated as yëpm (devil). As for interjections, by God was translated

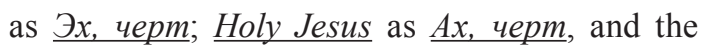
examples are numerous. This strategy allowed to keep Biblical link of the source text, but gave negative connotation to the positive statements. Thus, recognizing these intertextual elements, the translator, following the Soviet ideology or due to censorship requirements, decided to substitute them with their antonyms, changing connotation of the main characters' message and, consequently, the readers' perception.

\section{Conclusion}

Although the present study of the the analized works of fiction and their translations has shed some light on such most common strategies of ideological manipulation in the Soviet translation tradition as omissions (deletions), substitution and antonymous translation, further research should be conducted to expose the scope of the phenomenon in the Soviet, contemporary Russian and, in the long view, international translation tradition. The strategies, used by the translators in literary works, as a consequence of ideological manipulation, are not limited to the ones, identified in the article. Such complex phenomenon as ideological manipulation in translation in general and manipulation strategies in particular, require complex approach and thorough study to identify the full scope of the strategies used, the algorithm of ideological manipulation and the consequences it has on the target text.

\section{References}

Afzali, K. (2013). The Translator's Agency and the Ideological Manipulation in Translation: the Case of Political Texts in Translation Classrooms in Iran, In IJ-ELTS: International Journal of English Language \& Translation Studies, 1 (2), 196 - 208. Available at: http://eltsjournal.org/archive/value1\%20 issue2/13-1-2-13.pdf. Accessed 30.08.2016.

Dreiser, T. An American Tragedy. M, Foreign Languages Publishing House, 1951, 753 p.

Even-Zohar, I. (1978). The Position of Translated Literature within the Literary Polysystem, In Literature and Translation, 117-128.

Fairclough, N. (1989). Language and Power. Longman Group UK Limited, 259 p.

Gardenier, John; Resnik, David (2002). "The Misuse of Statistics: Concepts, Tools, And a Research Agenda”, In Accountability in Research: Policies and Quality Assurance, 9 (2), 65-74.

Jacques, T. (2002). Ideological Transformation Though Translation, In NUCB JLCC 4 (1), 13-19. Available at: http://www.nucba.ac.jp/themes/s_cic@cic@nucba/pdf/njlcc041/02JAQUES.PDF. Accessed 30.08.2016. 
James, H. The Portrait of a Lady. London, Marshall Cavendish Ltd., 1987, 576 p.

Klimovich, N. V. Manipulation in Translation (Exemplified by the International Elements' Translation), In Journal of Siberian Federal University, Humanities and Social Sciences, 8 (2), 2015, 244-151.

Lawrence, D.H. Lady Chatterley's Lover. London, Penguin Books, 1994, 365 p.

Lawrence, D.H. Sons and Lovers. London, Planet Three Publishing Network Ltd., 2004, 363 p.

Li, Li (2005). Ideological Manipulation in Translation in a Chinese Context: Su Manshu's Translation of Les Misérables, In Translation Studies (9)2. Available at: http://translationjournal.net/ journal/32ideology.htm. Accessed 30.08.2016.

Ledgerwood, S. D., Carpenter, p. R. (2012). A Framework for the Analysis of Market Manipulation, In Review of Law and Economics, 8(1), 253 - 295. Available at: http://www.brattle.com/system/ publications/pdfs/000/004/025/original/A_Framework_for_the_Analysis_of_Market_Manipulation_ Ledgerwood_Carpenter_Rev_Law__Econ_Sep_2012.pdf?1380310336.

Lefevere, A. (1992). Translation, Rewriting and the Manipulation of Literary Fame. London, New York, Routledge, $176 \mathrm{p}$.

Longman Dictionary of Contemporary English (2005). Pearson Education Limited, 1949 p.

Mei, Zhang (2012). Translation Manipulated by Ideology and Poetics-A Case Study of The Jade Mountain, In Theory and Practice in Language Studies, 2 (4), 754-758. Available at: http://www. academypublication.com/issues/past/tpls/vol02/04/15.pdf. Accessed 30.08.2016.

Morteza Mohammadi Hossein Abadi (2013). The Translator's Agencyand Ideological Manipulation in Translation: The Case of Political Texts in Translation Classes in Iran. Available at: http://idochp2. irandoc.ac.ir/FulltextManager/fulltext15/th/212/212233.pdf. Accessed 30.08.2016.

Nord, C. (2003). Function and Loyalty in Bible Translation, In M. Calzada-Pérez (ed.). Apropos of Ideology. Philadelphia: Multilingual Matters, 89-112.

Nasser Rashidi, Elham Karimi Fam (2011). Investigating The Possibility Of Ideological Effects And Discourse Shifts In Translation: A Critical Discourse Analysis, In The Journal of Linguistic and Intercultural Education (4), 111 - 124. Available at: http://www.uab.ro/jolie/2011/9_rashidi_karimifam. pdf. Accessed 30.08.2016.

Parenti, M. (2002), Monopoly Media Manipulation, Mediterranean Quarterly, 2002, 13(2), 56-66.

Pym, A. (2001). Introduction: The Return of Ethics to Translation Studies, 7 (2), 129-138.

Razumovskaya, V.A., Klimovich, N.V. Manipuliatsiia pri perevode intertekstual'nykh elementov $\mathrm{v}$ khudozhestvennom tekste [Manipulation in Intertextual Elements Translation in Fiction], In Bulletin of Moscow State Pedagogical University, Philology. Theory of Linguistics. Linguistic Education, 2016, 2 (22), 55-63.

Sapir, E. (1929). The Status of Linguistics as a Science, In E. Sapir (1958): Culture, Language and Personality (ed. D. G. Mandelbaum). Berkeley, CA, University of California Press.

Shokoufeh Amiri; Abdollah Baradaran (2015). The Study of Ideological Manipulation in Persian Translations of Noam Chomsky's Media Control Based on Farahzad's Translation Criticism Model, In Journal of Language and Translation, 5, 1(9), 33-41. Available at: http://ttlt.azad.ac.ir/article_518717 690a6a50e03b4ee92a8e64765ee87897.pdf. Accessed 30.08.2016.

Shuttleworth, M. (2004). Bytes and Mouthfuls: Sorting the Usable from the Risible in Machine Translation, In Bulletin of the Institute of Translation and Interpreting, September-October.

$$
-365-
$$


Steinbeck, J. The Grapes of Wrath. M, Progress Publishers, 1978, 530 p.

Stott, C. (2009). "Crowd Psychology \& Public Order Policing: An Overview of Scientific Theory and Evidence”. Liverpool School of Psychology, University of Liverpool. Available at: https://ru.scribd. com/doc/62156760/Crowd-Psychology-Public-Order-Policing-An-Overview-of-Scientific-Theoryand-Evidence Accessed. 09. 09. 2016.

Toury, G. (2000). The Nature and Role of Norms in Translation, In The Translation Studies Reader, ed. by L. Venuti. London, Routledge, 198-211.

Van Dijk, T.A. (2006). Discourse and Manipulation, In Discourse \& Society, 17(2), 359-383. Available at: http://www.discourses.org/OldArticles/Discourse\%20and\%20manipulation.pdf. Accessed 30.08.2016.

Venuti, L. The Translator's Invisibility: A History of Translation. London, Routledge, 2008, $336 \mathrm{p}$.

Whorf, B. L. (1940). Science and Linguistics, In Technology Review 42(6), 229 - 231, 247 - 248.

Whorf, B. L. (1956). Language, Thought and Reality (ed. J. B. Carroll). Cambridge, MA: MIT Press.

\section{Идеологическая манипуляция}

в переводах английской

и американской литературы

на русский язык

Н.В. Климович

Сибирский федеральный университет Россия, 660041, Красноярск, пр. Свободный, 79

Переводы английской и американской литературы кониа ХІХ - начала ХХ века, выполненные в советский период, характеризуются значительным идеологическим влиянием. Находясь под влиянием идеологии данной эпохи, переводчики подвергали переводные тексть изучаемых в статье произведений многочисленным изменениям. Посредством сравнительносопоставительного анализа текстов оригинала и текстов перевода автор пытается выявить наиболее распространенные манипулятивные стратегии, используемые советскими переводчиками художественных произведений, пытающихся соответствовать жестким требованиям институциональной цензуры и правящей партии страны рассматриваемого периода.

Ключевые слова: манипуляиия, идеология, перевод, трансформация, манипулятивные стратегии, сознательная манипуляция, бессознательная манипуляция.

Научная специиальность: 10.00.00 - филологические науки; 24.00.00 - культурология. 